\title{
Should fertilizer recommendations be adapted to parkland agroforestry systems? Case studies from Ethiopia and Rwanda
}

\author{
Tesfaye Shiferaw Sida 1 - Frédéric Baudron • \\ Alain Ndoli • Dereje Tirfessa • Ken E. Giller
}

Received: 28 December 2018 / Accepted: 20 August 2019/Published online: 4 September 2019

(C) The Author(s) 2019

\begin{abstract}
Aims This study aimed to disentangle tree-cropfertilizer interactions in agroforestry systems, which has been suggested as an entry point for sustainable intensification of smallholder farming systems in sub-Saharan Africa (SSA). Although tree-crop systems generate multiple economic and ecological benefits, tree-crop competition commonly occurs. We hypothesized that mineral fertilizers affect facilitative and competitive interactions differently in tree-crop systems.

Methods Tree-crop-fertilizer interactions were explored for wheat growing under Faidherbia albida, and maize
\end{abstract}

Responsible Editor: Remi Cardinael.

Electronic supplementary material The online version of this article (https://doi.org/10.1007/s11104-019-04271-y) contains supplementary material, which is available to authorized users.

\section{T. S. Sida $(\bowtie) \cdot$ D. Tirfessa}

International Maize and Wheat Improvement Center

(CIMMYT)-Ethiopia, Shola Campus, ILRI, P.O. Box 5689, Addis

Ababa, Ethiopia

e-mail: tesfayesida@gmail.com

e-mail: tesfaye.sida@wur.nl

\section{T. S. Sida · A. Ndoli $\cdot$ K. E. Giller}

Plant Production Systems, Wageningen University, P.O. Box 430, 6700 AK, Wageningen, The Netherlands

\section{F. Baudron - A. Ndoli}

International Maize and Wheat Improvement Center (CIMMYT), Southern Africa Regional Office, P. O. Box MP 163, Mazowe

Road, Harare, Zimbabwe growing under Acacia tortilis and Grevillea robusta through omission trials of nitrogen $(\mathrm{N})$ and phosphorus (P) in open fields and fields under tree canopy, using a split plot design. The experiments were conducted in Ethiopia and Rwanda, replicated four times, and over two seasons. Results Our results demonstrated that the presence of F. albida significantly improved $\mathrm{N}$ and $\mathrm{P}$ use efficiencies, leading to significantly higher $(P<0.001)$ grain yields in wheat. This tree species contributed around $64 \mathrm{~kg} \mathrm{ha}^{-1} \mathrm{yr}^{-1}$ of mineral $\mathrm{N}$. The $\mathrm{P}$ use efficiency of wheat under F. albida was double that of open field wheat. By contrast, G. robusta and A. tortilis trees lowered nutrient use efficiencies in maize, leading to significantly less maize grain yields compared with open fields receiving the same fertilization. Probabilities of critically low crop yields and crop failure were significantly greater for maize growing under the canopy of these species.

Conclusions Our results showed that recommended fertilizer rates led to facilitative interaction only with F. albida, highlighting that fertilizer recommendations need to be adapted to agroforestry systems.

Keywords Tree-crop interaction · Competition · Facilitation - Agronomic use efficiency · Crop failure . Mineral fertilizer

\section{Introduction}

In many smallholder farming systems of sub-Saharan Africa (SSA), poor soil fertility is a major limitation to 
crop production (Barrett and Bevis 2015). Insufficient nutrient input causes low crop yields (Vanlauwe et al. 2011; Barrett and Bevis 2015), fuelling a vicious cycle of soil degradation, low productivity and poverty in the region. The problem is compounded by the fact that most smallholders are resource-constrained and can only afford limited quantities of mineral fertilizers (Sileshi et al. 2009; Yirga and Hassan 2010). Even where farmers apply inorganic fertilizers, soils in many parts of the tropics are unresponsive (Vanlauwe et al. 2011). A large proportion of soils in SSA are unresponsive due to limited soil organic matter and reduction in biological functions, undermining immediate gains from application of mineral fertilizers (Tittonell and Giller 2013). There is a need for integrated soil fertility management (ISFM) - whereby mineral and organic nutrient sources are utilized efficiently. As sources of soil organic matter are scarce, agroforestry trees offer a viable path to increase inputs of organic matter in SSA (Lahmar et al. 2012).

In addition to improving soil nutrients through atmospheric nitrogen $(\mathrm{N})$ fixation by some leguminous species (Giller 2001), agroforestry trees may improve soil fertility by increasing soil organic matter (Teklay et al. 2006; Gnankambary et al. 2008). Organic matter accumulating from decomposing plant parts play a critical role in improving soil quality and enhancing longerterm soil productivity in most smallholder farming systems in the tropics (Sanchez et al. 1997; Palm et al. 2001). Organic inputs from Gliricidia sepium, for example, resulted in higher $\mathrm{N}$ and phosphorus (P) uptake by maize in Malawi (Akinnifesi et al. 2007).

As these trees also compete with crops for soil resources (Bertomeu et al. 2011), an understanding of the interactions between on-farm trees and mineral fertilizer is needed to manage tree-crop interactions (positive or negative). It has been established that there is an increase in soil carbon under trees (Bayala et al. 2015). This improves soil physical properties through soil aggregate formation and increased biological activities in the soil (Bayala et al. 2008), leading to lower soil density and improved soil porosity for better water infiltration under tree canopies compared with bare soils (Bayala et al. 2007; Sanou et al. 2010; Bargués Tobella et al. 2014). The presence of trees improves soil chemical fertility through addition of organic matter, which serves as the source of nutrients through decomposition (Rao et al. 1997). The trees also improve understory microclimate and the increased accumulation of soil organic matter creates favourable conditions for the microorganisms that thrive under their crowns compared with open field conditions. In addition to these improved soil conditions, trees reduce radiation underneath their crowns, leading to favourable condition for the associated crops (Sida et al. 2018b). Regardless of these improvements in soil conditions, improved yield in associated crops has not been automatically observed (Ndoli et al. 2017). According to Bayala et al. (2008), one of the reasons for these tree-associated improvements not to lead to an increase in crop yield is that both the tree and the crop are sharing the same pool of nutrients and soil water. Under those circumstances, it is common that the competition for these resources causes poor performance in associated crops, which in most cases are the less competitive species. Mineral fertilizer amendments may potentially offset such competition and improve crop performance. We hypothesized that facilitative and competitive interactions are affected by the use of mineral fertilizers. In addition, these tree-crop interactions could vary depending on agroecology, tree species and crop species.

Most studies conducted so far to improve tree-crop interactions have focused on tree management practices, in particular, root and canopy pruning (Jackson et al. 2000). However, studies exploring the impact of combining trees with mineral fertilizers on crop performance have been scarce. Thus, the current study aimed to (i) understand the impact of different combinations of $\mathrm{N}$ and $\mathrm{P}$ fertilizers on crop yield in treecrop systems and (ii) evaluate mineral fertilizer-tree combinations that maximize agronomic nutrient use efficiencies (AE) in different agroecologies.

\section{Materials and methods}

Site description

This study was conducted in two countries, Ethiopia and Rwanda, where retaining scattered trees in fields have been practiced for centuries. The study was conducted under three different agroecologies. Mojo $\left(8.509^{\circ} \mathrm{N}\right.$ and $\left.39.071^{\circ} \mathrm{E}\right)$ is located in the Central Rift Valley of Ethiopia at an elevation of $1665 \mathrm{~m}$ above sea level (m.a.s.l). The climate is semi-arid with average annual rainfall of $700 \mathrm{~mm} \mathrm{yr}^{-1}$ received mainly between June and October. The long-term mean daily temperature is $24.2{ }^{\circ} \mathrm{C}$ and the mean maximum daily temperature is 
$31{ }^{\circ} \mathrm{C}$. Temperature may peak above $35^{\circ} \mathrm{C}$. Andosol is the dominant soil type (RSO 2003), characterized by poor water holding capacity. Sparsely distributed F. albida is the main agroforestry species to which wheat (Triticum aestivum var. aestivum) and teff (Eragrostis tef) are associated in the area. F. albida in the study area is not undergoing reverse phenology (Sida et al. 2018b). It has been attributed to the heavy pruning performed towards the end of dry season. As a result, the trees produce freshly regenerating leaves during the wet cropping season.

Meki is also located in the Central Rift Valley of Ethiopia $\left(8.1855^{\circ} \mathrm{N}\right.$ and $\left.38.86^{\circ} \mathrm{E}\right)$ to the Southwest of Mojo at an elevation of 1500 m.a.s.l, and is characterized by a semi-arid climate. The annual average temperature is $19.3{ }^{\circ} \mathrm{C}$ and the average annual rainfall is $775 \mathrm{~mm}$. Similar to Mojo, Andosol is the dominant soil type. The area is dominated by savannah woodland vegetation type, where the retention of scattered trees during conversion to agriculture created agroforestry parklands. Although, the local farming systems are characterised by diverse crops in rotation, maize (Zea mays), bean (Phaseolus vulgaris) and sorghum (Sorghum bicolor) are the most dominant. Maize associated with $A$. tortilis represents the most dominant agroforestry practice in this area, and was thus, selected for our investigation.

A similar study was conducted in Bugesera, Rwanda $\left(2.354^{\circ} \mathrm{S}\right.$ and $\left.30.265^{\circ} \mathrm{E}\right)$, at an elevation of 1397 m.a.s.l. The area is characterized by bimodal rainfall with primary and secondary peaks in April and November, respectively. A short dry season - from January to mid-March - is followed by a long rainy season - from mid-March to June. A long dry season - from mid-June to September is then followed by a short rainy season - from mid-October to December. The annual rainfall ranges from 850 to $1000 \mathrm{~mm}$. This area has a dry season lasting for three months and an average temperature of $21^{\circ} \mathrm{C}$ (Verdoodt and Van Ranst 2003). Some of the dominant agroforestry tree species include G. robusta, Senna spectabilis and Euphorbia spp. Soils at Bugesera are humic and haplic Ferralsols. In Bugesera, the current study explored interactions between $G$. robusta and maize under different $\mathrm{N}$ and $\mathrm{P}$ fertilizer management.

Tree selection, experimental setup and data collection

Tree-crop-fertilizer interaction was explored for wheat growing under crowns of $F$. albida (Mojo, Ethiopia), and maize growing under A. tortilis (Meki, Ethiopia) and G. robusta (Bugesera, Rwanda). For each species, selected trees were located in a single field within a farm. We used key informant interviews, group discussions, DBH (diameter at breast height) estimates, and visual observations to select trees with approximately similar ages, crown structures, and pruning history. Most scattered tree species are known for their crown asymmetry (Sileshi et al. 2014). To avoid fertilizer redistribution problem because of these asymmetry, we purposively selected trees showing crowns very close to symmetrical distribution in the plot. We selected trees in such a way that North-South crown diameters did not deviate from East-West crown diameters by more than 5\% (Table 1). In addition, we assigned fertilizer treatments randomly so that the asymmetry effect on the result is minimized. As farmers usually prune trees every 2-3 years, we selected trees that are in their second season after pruning (i.e., the experiments had been completed before the trees reached the next pruning cycle). Plots measuring $10 \times 10 \mathrm{~m}$ were established around each tree, with the tree at the centre. The trees selected for the experiment were a minimum of $40 \mathrm{~m}$ away from any other tree in the field. Within the same field, another plot of the same size was established in an open field, at least $40 \mathrm{~m}$ away from any tree. The open fields were also a minimum of $40 \mathrm{~m}$ away from the experimental tree as well as any tree in the field. Each of these plots (under tree canopy and open field conditions) was split into four sub-plots, measuring $4 \times 4 \mathrm{~m}$ and received different mineral fertilizers. The $10 \times 10 \mathrm{~m}$ plots were considered main plots, while fertilization was a subplot factor. Open field and under canopy plots received inorganic fertilizers as: no fertilizer /control $\left(\mathrm{N}^{-}\right), \mathrm{P}$ only $\left(\mathrm{P}^{+} \mathrm{N}^{-}\right), \mathrm{N}$ only $\left(\mathrm{P}^{-} \mathrm{N}^{+}\right)$and combined $\mathrm{N}$ and $\mathrm{P}$ $\left(\mathrm{N}^{+} \mathrm{P}^{+}\right)$as sub-plot treatments (Fig. 1). The fertilizer treatments were randomly allocated within the main plots. In Ethiopia, this setting was replicated in four farms and repeated over two seasons. In Rwanda, the experiment was replicated in three farms and repeated over four seasons. Individual trees for a particular species were selected to be as similar as possible. Tree heights and canopy diameters (East-West and North-South) for the selected trees were measured to fix the DBH, canopy radius and height of the selected trees to be within 5\% of the size of the first purposively selected tree, in order to maintain reasonable similarity between selected trees.

Trees were managed following farmers' typical practices and plots were managed following recommended 
Table 1 Characteristics of trees used in the experiment

\begin{tabular}{llllll}
\hline Tree species & \multicolumn{2}{l}{ Algometric Characteristics } & & Age (Years) & Age estimation method \\
\cline { 2 - 4 } & DBH (cm) & Height (m) & Crown diameters (cm) & & \\
\hline F. albida & $60.5(5.3)$ & $16.8(2.2)$ & $13.2(2.4)$ & $73.4(6.7)$ & (Sida et al. 2018) \\
A. tortilis & $29.7(2.9)$ & $6.8(0.6)$ & $18.3(2.3)$ & $59.5(6.8)$ & (Martin and Moss 1997) \\
G. robusta & $24.7(2.3)$ & $8.4(0.5)$ & $2.4(0.2)$ & $17.0(0.0)$ & (Kuyah et al. 2012) \\
\hline
\end{tabular}

practices. Wheat variety 'Kilinto', maize varieties 'Melkasa-2 and PAN4M21, which were well-adapted to the respective environmental conditions, were used in Mojo, Meki and Bugesera, respectively. Plots where N was used as a treatment were fertilized with $64 \mathrm{~kg} \mathrm{ha}^{-1} \mathrm{~N}$ (split applied $50 \%$ at sowing and the remaining side dressed six weeks after planting). In plots where $\mathrm{P}$ was used as treatment, $30 \mathrm{~kg} \mathrm{ha}^{-1} \mathrm{P}$ was broadcasted at sowing. For wheat in Mojo, seed was drilled at a spacing of $20 \mathrm{~cm}$ between rows at a rate of $150 \mathrm{~kg} \mathrm{ha}^{-1}$. For maize in Meki and Bugesera, a recommended spacing of $70 \mathrm{~cm}$ between rows and $30 \mathrm{~cm}$ between plants was used.

Crop growth and development data were collected at two weeks interval starting 30 days after planting. At harvest, dry biomass and grain yields were estimated. For maize, yield was sampled from five central rows, leaving the border rows. For wheat, yield was estimated from a sub-plot of $9 \mathrm{~m}^{2}$ at the centre of the experimental plots. For both crops, samples were dried at $65{ }^{\circ} \mathrm{C}$ for $48 \mathrm{~h}$ to estimate dry matter yield.

\section{Data analysis}

Because our data was generated from contrasting seasons and agroecologies, we made comparisons of treatment effects for each site separately. We used split plot
ANOVA for mean separation in R ( $\mathrm{R}$ Core Team 2017). In the model (Eq. 1), treatment (i.e., under canopy vs open field) was considered main plot factor, while fertilization was treated as a sub-plot factor.

$$
\begin{aligned}
Y_{i j(k)}= & \alpha+\beta T R_{i(k)}+\gamma F R_{j}+\lambda\left(T R_{i(k)} \mathrm{x} F R_{j}\right) \\
& +\mu\left(F R_{j(k)} \mathrm{x} S N_{k}\right)+\mu\left(T R_{i(k)} \mathrm{x} S N_{k}\right)+\varepsilon
\end{aligned}
$$

where, $Y_{\mathrm{ij}(\mathrm{k})}$ represents across season maize or wheat grain yield, $\mathrm{TR}_{\mathrm{i}(\mathrm{k})}$ is the $\mathrm{i}^{\text {th }}$ treatment (i.e., under tree canopy or in open field condition) nested within the $\mathrm{k}^{\text {th }}$ season, $\mathrm{FR}_{\mathrm{j}}$ is the $\mathrm{j}^{\text {th }}$ type of fertilizer, $\mathrm{SN}_{\mathrm{k}}$ is the $\mathrm{k}^{\text {th }}$ season, $\varepsilon$ is the residual, and where, $\alpha, \beta, \gamma, \mu$ and $\lambda$ represent regression coefficients for the main and interaction effects. The effect 'season' was used as a grouping variable (i.e., the comparison between treatments was performed, ignoring the variation between seasons), while farms were treated as replications in the model. Interactions and main effects that had little explanatory power, i.e., variables with $F$-values lower than 0.1 , were removed. Statistical analysis was performed with square-root-transformed values for maize grain yield from Meki to follow normal distribution. For Bugesera, the grain yield followed a Poisson distribution and its data was analysed assuming this distribution. Where transformed data were used, mean comparison was

Fig. 1 Field layout for fertilizertree combinations. Control (no fertilizer applied), $\mathrm{P}$ only

(30 kg ha $\left.{ }^{-1} \mathrm{P}\right), \mathrm{N}$ only

$\left(64 \mathrm{~kg} \mathrm{ha}^{-1} \mathrm{~N}\right)$ and NP

$\left(30 \mathrm{~kg} \mathrm{ha}^{-1} \mathrm{P}\right.$ with $\left.64 \mathrm{~kg} \mathrm{ha}^{-1} \mathrm{~N}\right)$ fertilization rates.

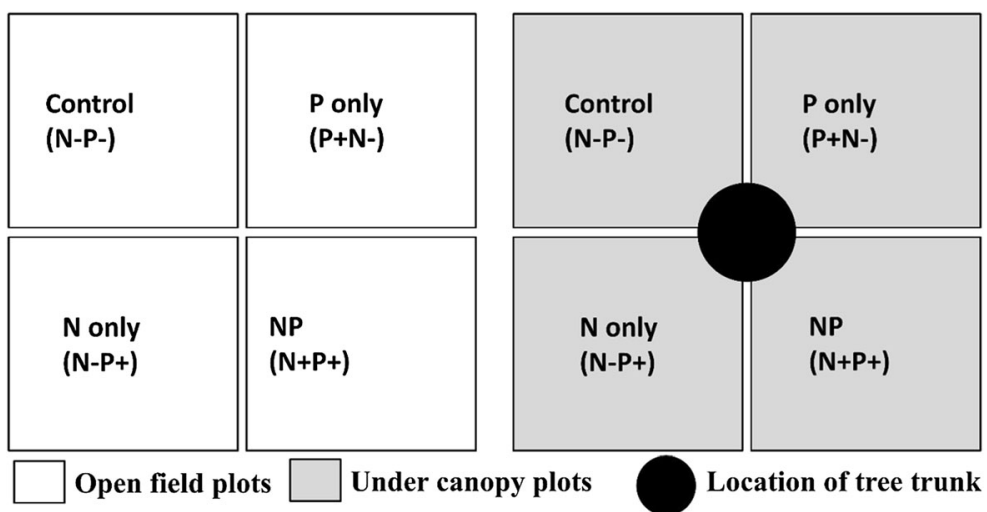


made on a back-transformed least squared mean, i.e., on the mean that was adjusted for other factors.

In addition to causing variations in yield, the treatments are likely to be associated to crop failures or extremely low yields. The probabilities of crop failure and low yields were computed using Eqs. 2 and 3.

$\mathrm{P}_{0}=\left(\frac{\mathrm{Y}_{0}}{\mathrm{Y}_{\mathrm{t}}}\right)$

where, $\mathrm{P}_{0}$ is the proportion of plots characterized by crop failure for a given treatment, $\mathrm{Y}_{0}$ is the number of plots characterized by crop failure (i.e. plots yielding no grain harvest at all) and $\mathrm{Y}_{\mathrm{t}}$ is the total number of plots in the whole experiment.

$P_{i}=\left(\frac{Y_{i}}{Y_{t}}\right)$

Where, $\mathrm{P}_{\mathrm{i}}$ is the proportion of plots characterized by critically low crop yield under a given treatment, $\mathrm{Y}_{\mathrm{i}}$ is the total number of plots with critically low crop yield and $Y_{t}$ is the number of plots in the whole experiment. All yields that were two standard deviations lower than the mean grain yield were considered critically low.

We also computed agronomic nitrogen use efficiency (NUE) and phosphorus use efficiency (PUE) for under canopy and open field treatments using Eqs. 4 and 5, respectively (Vanlauwe et al. 2011). This was mainly because we hypothesized that the possible increase in organic matter content under the canopy of trees may improve nutrient use efficiencies in agroforestry systems.

$\mathrm{NUE}=\left(\frac{\mathrm{Y}_{\mathrm{N}}-\mathrm{Y}_{\mathrm{C}}}{\mathrm{F}_{\mathrm{APN}}}\right)$

where, NUE represents agronomic use efficiency for nitrogen $(\mathrm{kg} / \mathrm{kg}), \mathrm{Y}_{\mathrm{N}}$ represents grain yield $\left(\mathrm{kg} \mathrm{ha}^{-1}\right)$ from treatments where nitrogen fertilizer was applied, $Y_{C}$ represents grain yield from the control (open field treatments where no fertilizer was used $\left.\left[\mathrm{kg} \mathrm{ha}^{-1}\right]\right)$ and $\mathrm{F}_{\mathrm{APN}}$ represents the amount of nitrogen fertilizer applied as a treatment $\left(\mathrm{kg} \mathrm{ha}^{-1}\right)$.

$\mathrm{PUE}=\left(\frac{\mathrm{Y}_{\mathrm{P}}-\mathrm{Y}_{\mathrm{C}}}{\mathrm{F}_{\mathrm{APP}}}\right)$

where, PUE represents agronomic use efficiency for phosphorus $(\mathrm{kg} / \mathrm{kg}), Y_{P}$ represents grain yield from treatments where phosphorus fertilizer was applied $\left(\mathrm{kg} \mathrm{ha}^{-1}\right), \mathrm{Y}_{\mathrm{C}}$ represents grain yield from the control (open field treatments where no fertilizer was used $\left.\left[\mathrm{kg} \mathrm{ha}^{-1}\right]\right)$ and $\mathrm{F}_{\mathrm{APP}}$ represents the amount of phosphorus fertilizer applied in the treatment $\left(\mathrm{kg} \mathrm{ha}^{-1}\right)$.

Equations (4) and (5), respectively, were applied for treatments where $\mathrm{N}$ and $\mathrm{P}$ were applied. Treatments that did not receive the respective nutrients were excluded from the analysis on nutrient use efficiencies.

\section{Results}

Crop yield reductions and failures under tree-crop-fertilizer interactions

Neither crop failure nor critically low yield was recorded from $F$. albida-wheat systems. The probabilities of maize yield reduction in A. tortilis-maize and G. robusta-maize systems were influenced both by the presence or absence of trees and the type of $\mathrm{N}$ and $\mathrm{P}$ combinations used (Fig. 2).

In G. robusta-maize systems in Bugesera (Fig. 2), the probabilities of crop failure for under canopy maize were $25.0 \%, 15.0 \%, 17 \%$ and $8.0 \%$, for the control, $\mathrm{P}$ only, N only and combined NP treatments respectively. By comparison, the probabilities of crop failure in maize were less in the open field. It was $10.0 \%, 7.5 \%, 6.0 \%$ and $7.0 \%$, respectively, for the control, $\mathrm{P}$ only, $\mathrm{N}$ only and combined NP fertilizer applications. The probabilities of critically low maize yield in under canopy treatments that received no fertilizer, $\mathrm{N}$ only, $\mathrm{P}$ only and $\mathrm{NP}$ were $45.0 \%, 33.0 \%, 33.0 \%$ and $13.3 \%$, respectively. The probabilities of such a low yield were relatively lower for the corresponding open field treatments at around $8.0 \%$ for all treatments.

In A. tortilis-maize systems in Meki (Fig. 2), the probabilities of critically low maize yield in under canopy treatments that received no fertilizer, $\mathrm{N}$ only, $\mathrm{P}$ only and NP were $13.3 \%, 13.3 \%, 8 \%$ and $8 \%$, respectively. For the open fields, there was no critically low yield under the combined application of NP. The probability of crop failure for the other fertilizer treatments (control, $\mathrm{N}$ only and $\mathrm{P}$ only) in the open fields was similar: around $8 \%$.

Effect of NP fertilizers on wheat yield in F. albida-wheat systems

The presence of $F$. albida trees and fertilizer application showed a statically significant effect $(P<0.05)$ on wheat grain yield in Mojo (Table 2 and Fig. 3). The interaction between the type of NP fertilizer used and 
Fig. 2 The probability of crop failure (no grain yield) and critically low yield (yields of -2 standard deviations from the mean) in A. tortilis-maize and G. robusta-maize systems with control ( $\left.\mathrm{N}^{-} \mathrm{P}^{-}\right), \mathrm{P}$ only $\left(\mathrm{N}^{-} \mathrm{P}^{+}\right), \mathrm{N}$ only $\left(\mathrm{N}^{+} \mathrm{P}^{-}\right)$and $\mathrm{NP}\left(\mathrm{N}^{+} \mathrm{P}^{+}\right)$ fertilizer applications. Note: the broken vertical lines represent the threshold for critically low yield, calculated as the difference between the mean and two standard deviations, while the solid vertical lines represent the sum of the mean and two standard deviations.

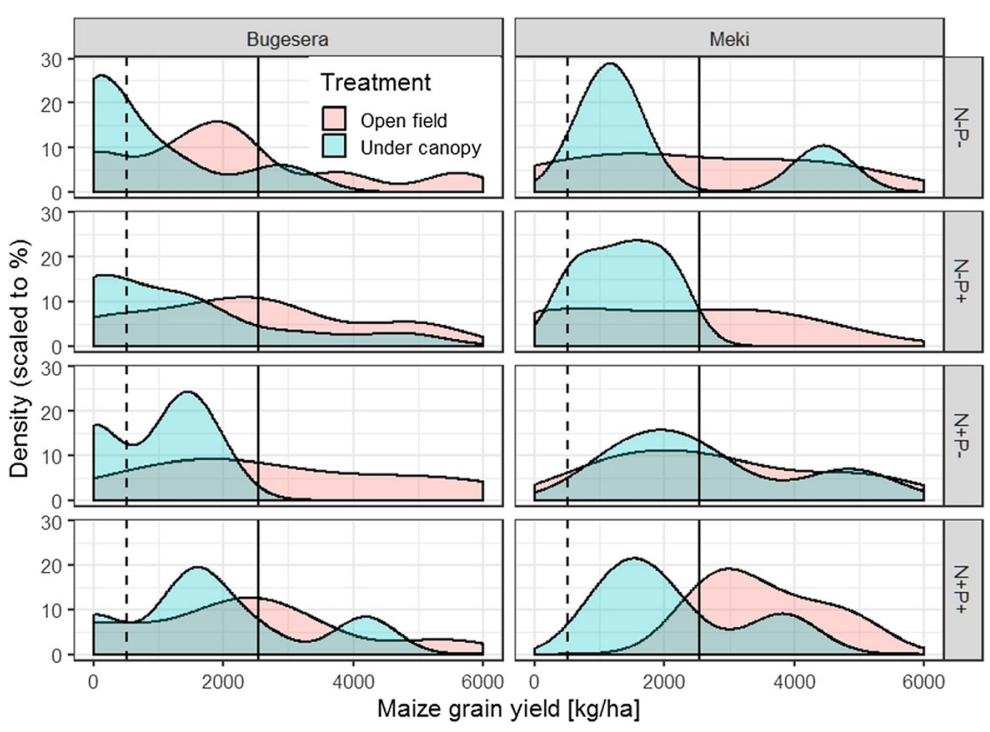

the presence of $F$. albida trees was also statistically significant $(P<0.001)$.

Grain yield under the tree canopy was significantly higher $(P<0.001)$ than grain yield in the open fields

Table 2 Summary of the results of GLMM models for explaining the variability in grain yields under F. albida-wheat (Ethiopia, $n=$ 4), A. tortilis-maize (Ethiopia, $\mathrm{n}=4$ ) and G. robusta-maize (Rwanda, $n=3)$ systems. Probabilities of significant effects $(P<0.05)$ are indicated in bold

\begin{tabular}{lllll}
\hline Tree species & Effects & Df & F-value & $P$ value \\
\hline F. albida & Treatment (tree) & 1 & 67.7 & $<\mathbf{0 . 0 0 0 1}$ \\
& Fertilizer & 3 & 43.6 & $<\mathbf{0 . 0 0 0 1}$ \\
& Season & 1 & 2.2 & 0.1480 \\
& Treatment: fertilizer & 3 & 19.6 & $<\mathbf{0 . 0 0 0 1}$ \\
& Treatment: season & 1 & 1.4 & 0.2380 \\
A. tortilis & Fertilizer: season & 3 & 0.7 & 0.5410 \\
& Treatment (tree) & 1 & 11.8 & $\mathbf{0 . 0 0 1 6}$ \\
& Fertilizer & 3 & 109.8 & $<\mathbf{0 . 0 0 0 1}$ \\
& Season & 1 & 0.8 & 0.4926 \\
& Treatment: fertilizer & 3 & 0.3 & 0.8544 \\
& Treatment: season & 1 & 0.6 & 0.4276 \\
& Fertilizer: season & 3 & 0.4 & 0.7550 \\
& Treatment (tree) & 1 & 8693.8 & $\mathbf{0 . 0 2 6 8}$ \\
& Fertilizer & 3 & 1887.0 & $<\mathbf{0 . 0 0 0 1}$ \\
& Season & 3 & 8117.7 & $<\mathbf{0 . 0 0 0 1}$ \\
& Treatment: fertilizer & 3 & 801.5 & $\mathbf{0 . 0 0 1 5}$ \\
& Treatment: season & 3 & 368.1 & $\mathbf{0 . 0 0 0 2}$ \\
& Fertilizer: season & 9 & 78.8 & $<\mathbf{0 . 0 0 0 1}$ \\
\hline & & & &
\end{tabular}

(Table 2), when both treatments did not receive any fertilizer. Application of $\mathrm{P}$ only to wheat under canopy produced significantly higher $(P<0.001)$ grain yield than any open field treatments, except the NP treatment. For example, application of $\mathrm{P}$ only to wheat under canopy resulted in twice as much grain yield as wheat in open field plots receiving the same fertilization.

The $\mathrm{N}$ only treatment resulted in comparable wheat grain yield in open field and under canopy treatments, indicating that $\mathrm{N}$ fertilization of wheat under canopy did not lead to yield gain, contrasting with $\mathrm{P}$ fertilization. Combined application of $\mathrm{N}$ and $\mathrm{P}$ produced significantly higher $(P<0.001)$ grain yield for wheat under canopy of $F$. albida compared with wheat in open fields. The combined NP treatment under canopy produced significantly larger yield than any other treatments. Open field wheat did not respond to application of $\mathrm{P}$ only fertilizer, resulting in yields that were comparable with the control treatment (Fig. 3) and significantly smaller than under canopy wheat receiving no fertilization.

\section{Effect of NP fertilizers on maize yield in A. tortilis-maize systems}

Under A. tortilis-maize systems in Meki (Table 1 and Fig. 4), maize yields were lower under tree canopy than in open fields $(P<0.001)$. Mean maize grain yield in the open field was significantly $(P<0.05)$ higher than maize grain yield under the canopy of $A$. tortilis, regardless of the $\mathrm{N}$ and $\mathrm{P}$ treatment used (Table 2). 


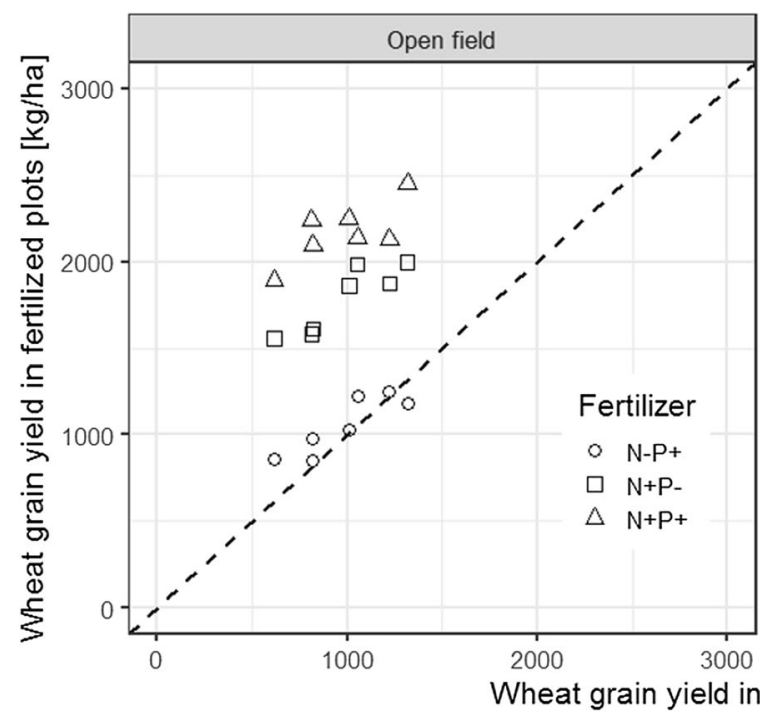

Fig. 3 Comparison of wheat grain yield in control plots and in fertilized plots, with different application of mineral fertilizer in open field conditions or under the canopy of F. albida. $N^{+} P^{-}$, $N P^{+}$and $N^{+} P^{+}$indicate nitrogen only, phosphorus only and

With further mean comparison (Table 3), there was no significant difference in grain yield between the open field and under canopy control. Application of N-containing fertilizer ( $\mathrm{N}$ alone and combined $\mathrm{NP}$ ) to the open fields resulted in significantly higher yields compared with the open field control and all under canopy treatments (Control, $\mathrm{P}, \mathrm{N}$ and NP). Application of $\mathrm{P}$ only to open field produced comparable grain yields to under canopy maize that received no fertilizer. $\mathrm{N}$ only and combined NP fertilizers applied to under canopy plots resulted in maize

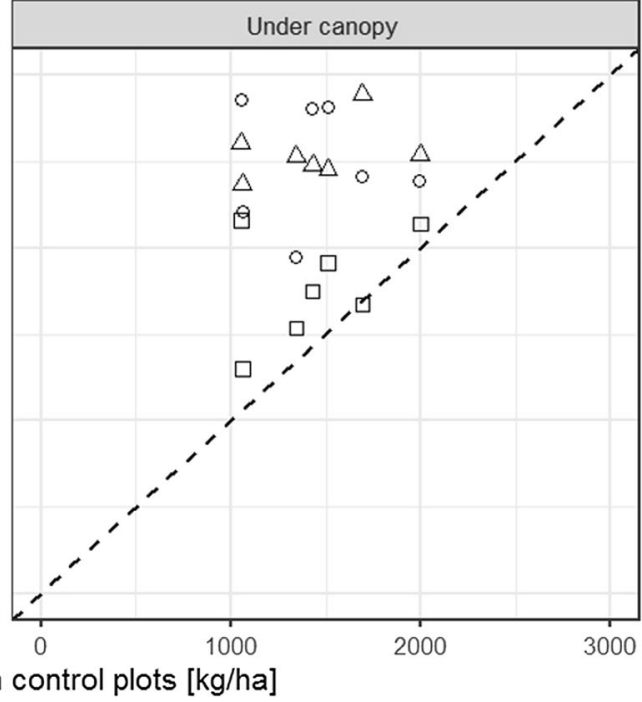

combination of nitrogen and phosphorus fertilizers, respectively. Control plot represent open field plot that did not receive any fertilization. Broken lines represent 1:1 line

grain yields that were only comparable to open field plots without any fertilization (control). Under canopy maize that received $\mathrm{P}$ only, resulted in significantly higher yields than under canopy plots that received no fertilizer.

Effect of NP fertilizers on maize yield in G. robusta-maize systems

For G. robusta in Bugesera (Table 1 and Fig. 4), the presence of trees and fertilizer application showed a
Fig. 4 Boxplots showing grain yield in open field and in under canopy plots, with different applications of $\mathrm{N}$ and $\mathrm{P}$ fertilizers in open field conditions or under the canopies of $G$. robusta (Bugesera) and $A$. tortilis (Meki). $N P^{-}, N^{+} P^{-}, N P^{+}$and $N^{+} P^{+}$, respectively, indicate control, only nitrogen, only phosphorus and combined nitrogen and phosphorus fertilizers

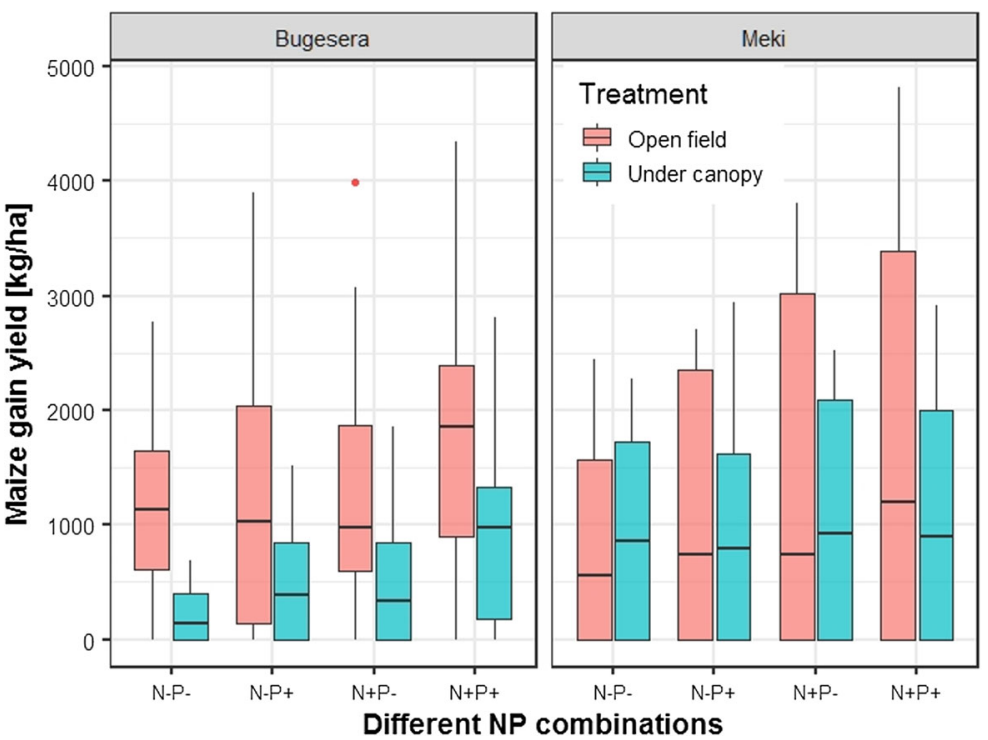


statically significant effect $(P<0.05)$ on maize grain yield. The presence of $G$. robusta trees significantly reduced maize grain yield $(P<0.05)$, regardless of the fertilization used (Table 4). All under canopy treatments resulted in significantly $(P<0.001)$ less maize yield compared with any of the treatments in the open fields. The only exception was under canopy maize that received combined NP fertilizers, which was the highest yielding among all under canopy treatments. It resulted in comparable (only 5.4\% lower) maize yield with the open field maize that did not receive any fertilizer (control). Compared with the unfertilized maize in the open field, the presence of G. robusta trees resulted in a $75.7 \%, 61.0 \%$ and $50.0 \%$ reduction in grain yield for no fertilizer, $\mathrm{P}$ only and $\mathrm{N}$ only treatments, respectively. For open fields, separate application of either $\mathrm{N}$ or $\mathrm{P}$ fertilizers resulted in comparable maize yields. By contrast, application of $\mathrm{N}$ only resulted in significantly higher maize yield than application of $\mathrm{P}$ only to under canopy maize.

Table 3 Mean comparison for grain yield [mean (se)] as affected by combinations of N-P fertilizers under and outside the canopies of F. albida (wheat) in Mojo and A. tortilis (maize) in Meki,
An interesting result from G. robusta-maize systems was that with the control, use of $\mathrm{P}$ only, $\mathrm{N}$ only and combined NP fertilizers (Table 4 and Fig. 4), maize grain yield under the canopy showed a progressive and significant increase $(P<0.001)$. This can point to the conclusion that fertilizer rates different from those currently recommended for the area may enhance productivity of maize in these systems (Table 4).

Tree-crop interactions and agronomic fertilizer use efficiencies

NUE and PUE varied across tree-crop systems (Figs. 5 and 6). In F. albida-wheat systems (Fig. 5a), application of $\mathrm{N}$ only fertilizer did not improve NUE of under canopy wheat compared with open field wheat. By contrast, NUE was $17.4 \%$ higher for under canopy compared with open field treatments when combined $\mathrm{NP}$ fertilizer was used (i.e., $23 \mathrm{~kg}$ grain for every $\mathrm{kg}$ of $\mathrm{N}$

Ethiopia. Means followed by similar letters within a column are not significantly different at the $5 \%$ probability level

\begin{tabular}{|c|c|c|c|c|}
\hline \multirow[t]{2}{*}{ Tree species } & \multicolumn{2}{|l|}{ Treatments } & \multicolumn{2}{|c|}{ Wheat grain yield $\left(\mathrm{kg} \mathrm{ha}^{-1}\right)$} \\
\hline & Canopy & Fertilizer & Season 2014 & season 2015 \\
\hline \multirow[t]{10}{*}{ F. albida } & \multirow[t]{4}{*}{ Open field } & $\mathrm{N}^{-} \mathrm{P}^{-}$ & $1090(225)^{\mathrm{a}}$ & $718(127)^{\mathrm{a}}$ \\
\hline & & $\mathrm{N}^{-} \mathrm{P}^{+}$ & $1078(179)^{\mathrm{a}}$ & $1020(108)^{a}$ \\
\hline & & $\mathrm{N}^{+} \mathrm{P}^{-}$ & $1829(177)^{b}$ & $1717(135)^{\mathrm{b}}$ \\
\hline & & $\mathrm{N}^{+} \mathrm{P}^{+}$ & $2267(133)^{\mathrm{c}}$ & $1993(77)^{\mathrm{b}}$ \\
\hline & \multirow[t]{6}{*}{ Under canopy } & $\mathrm{N}^{-} \mathrm{P}^{-}$ & $1496(148)^{\mathrm{b}}$ & $1370(313)^{\mathrm{c}}$ \\
\hline & & $\mathrm{N}^{-} \mathrm{P}^{+}$ & $2493(408)^{\mathrm{cd}}$ & $2482(191)^{\mathrm{d}}$ \\
\hline & & $\mathrm{N}^{+} \mathrm{P}^{-}$ & $1716(157)^{\mathrm{b}}$ & $1865(283)^{\mathrm{b}}$ \\
\hline & & $\mathrm{N}^{+} \mathrm{P}^{+}$ & $2585(203)^{\mathrm{d}}$ & $2502(71)^{\mathrm{d}}$ \\
\hline & & $\operatorname{LSD}\left(\mathrm{kg} \mathrm{ha}^{-1}\right)$ & 226.6 & 303.7 \\
\hline & & $\mathrm{CV}(\%)$ & 12.1 & 19.0 \\
\hline \multirow[t]{10}{*}{ A. tortilis* } & \multirow[t]{4}{*}{ Open field } & $\mathrm{N}-\mathrm{P}-$ & $2076(421)^{\mathrm{a}}$ & $1656(126)^{\mathrm{a}}$ \\
\hline & & $\mathrm{N}^{-} \mathrm{P}^{+}$ & $2802(644)^{\mathrm{bc}}$ & $1844(632)^{\mathrm{a}}$ \\
\hline & & $\mathrm{N}^{+} \mathrm{P}^{-}$ & $3170(502)^{\mathrm{b}}$ & $2479(201)^{\mathrm{b}}$ \\
\hline & & $\mathrm{N}^{+} \mathrm{P}^{+}$ & $3465(555)^{\mathrm{b}}$ & $3854(545)^{\mathrm{c}}$ \\
\hline & \multirow[t]{6}{*}{ Under canopy } & $\mathrm{N}^{-} \mathrm{P}^{-}$ & $1518(201)^{\mathrm{a}}$ & $1146(112)^{\mathrm{a}}$ \\
\hline & & $\mathrm{N}^{-} \mathrm{P}^{+}$ & $2386(460)^{\mathrm{c}}$ & $1354(339)^{\mathrm{a}}$ \\
\hline & & $\mathrm{N}^{+} \mathrm{P}^{-}$ & $1951(307)^{\mathrm{a}}$ & $1396(229)^{\mathrm{a}}$ \\
\hline & & $\mathrm{N}^{+} \mathrm{P}^{+}$ & $2102(192)^{\mathrm{a}}$ & $1563(222)^{\mathrm{a}}$ \\
\hline & & $\operatorname{LSD}\left(\mathrm{kg} \mathrm{ha}^{-1}\right)$ & 710.0 & 771.2 \\
\hline & & $\mathrm{CV}(\%)$ & 31.2 & 39.0 \\
\hline
\end{tabular}

*In 2015 maize failed from the majority of the plots because of El Niño and only the maize Stover was analyzed. 
Table 4 Mean comparison for maize grain yield [log-mean (se)] as affected by combinations of N-P fertilizers under and outside the canopies of G. robusta in Bugesera, Rwanda. Means followed by similar letters within a column are not significantly different at the $5 \%$ probability level

\begin{tabular}{|c|c|c|c|c|c|c|}
\hline \multirow[t]{3}{*}{ Tree species } & \multicolumn{2}{|l|}{ Treatments } & \multicolumn{4}{|c|}{ log-grain yield $\left(\mathrm{kg} \mathrm{ha}^{-1}\right)$} \\
\hline & \multirow[t]{2}{*}{ Canopy } & \multirow[t]{2}{*}{ Fertilizer } & \multicolumn{4}{|l|}{ Seasons } \\
\hline & & & $2015 \mathrm{~A}$ & 2015B & $2016 \mathrm{~A}$ & 2016B \\
\hline \multirow[t]{10}{*}{ G. robusta } & \multirow[t]{4}{*}{ Open field } & $\mathrm{N}^{-} \mathrm{P}^{-}$ & $7.5(0.013)^{\mathrm{a}}$ & $6.4(0.023)^{\mathrm{a}}$ & $5.9(0.031)^{\mathrm{a}}$ & $7.5(0.014)^{\mathrm{a}}$ \\
\hline & & $\mathrm{N}^{-} \mathrm{P}^{+}$ & $7.7(0.012)^{\mathrm{b}}$ & $6.7(0.020)^{\mathrm{b}}$ & $6.1(0.028)^{\mathrm{b}}$ & $7.5(0.013)^{\mathrm{a}}$ \\
\hline & & $\mathrm{N}^{+} \mathrm{P}^{-}$ & $7.7(0.012)^{b}$ & $6.8(0.019)^{\mathrm{b}}$ & $6.1(0.027)^{\mathrm{b}}$ & $7.6(0.013)^{\mathrm{ab}}$ \\
\hline & & $\mathrm{N}^{+} \mathrm{P}^{+}$ & $7.9(0.011)^{\mathrm{c}}$ & $7.0(0.017)^{\mathrm{c}}$ & $6.4(0.024)^{\mathrm{c}}$ & $7.9(0.011)^{b}$ \\
\hline & \multirow[t]{6}{*}{ Under canopy } & $\mathrm{N}^{-} \mathrm{P}^{-}$ & $6.3(0.025)^{\mathrm{d}}$ & $4.6(0.059)^{\mathrm{d}}$ & $0.1(0.577)^{\mathrm{d}}$ & $5.8(0.032)^{\mathrm{c}}$ \\
\hline & & $\mathrm{N}^{-} \mathrm{P}^{+}$ & $6.4(0.023)^{\mathrm{d}}$ & $5.4(0.039)^{\mathrm{e}}$ & $3.5(0.100)^{\mathrm{e}}$ & $6.7(0.021)^{\mathrm{d}}$ \\
\hline & & $\mathrm{N}^{+} \mathrm{P}^{-}$ & $6.7(0.020)^{\mathrm{e}}$ & $5.7(0.033)^{\mathrm{f}}$ & $4.2(0.071)^{\mathrm{f}}$ & $7.0(0.017)^{\mathrm{e}}$ \\
\hline & & $\mathrm{N}^{+} \mathrm{P}^{+}$ & $7.4(0.014)^{\mathrm{a}}$ & $6.4(0.023)^{\mathrm{a}}$ & $4.6(0.059)^{\mathrm{g}}$ & $7.4(0.014)^{\mathrm{a}}$ \\
\hline & & $\log \operatorname{Lik}$ & -4869.5 & -7292.6 & -3989.4 & -6019.3 \\
\hline & & AIC & 9756.9 & 4613.8 & 7996.7 & 2056.5 \\
\hline
\end{tabular}

Means followed by similar letters within a column are not significantly different at the 5\% probability level. Letters A (season with long rains) and $\mathrm{B}$ (season with short rains), following the years represent a season within a year

applied on the open field wheat, while it was $27 \mathrm{~kg}$ for under tree canopy wheat, on average). This indicates that $\mathrm{P}$ is more limiting than $\mathrm{N}$ for wheat production under the canopy Of $F$. albida.

As illustrated on Fig. 5b, the presence of F. albida trees almost doubled PUE of wheat (39.2 $\mathrm{kg}$ of grain for every additional $\mathrm{kg}$ of $\mathrm{P}$ added) compared with open fields $(19.3 \mathrm{~kg}$ of grain for every

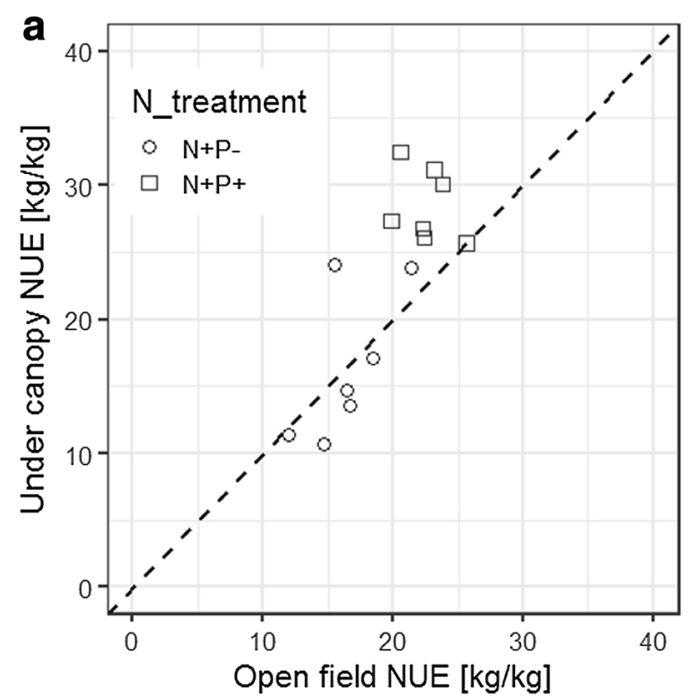

Fig. 5 Comparison of nitrogen use efficiencies (NUE) (a) and phosphorus use efficiencies (PUE) (b) in open field conditions and under the canopy of $F$. albida, with different fertilizer applications. additional $\mathrm{kg}$ of $\mathrm{P}$ added). Interestingly, PUE of open field wheat improved significantly with the application of N-containing fertilizer (i.e., $\mathrm{N}$ and NP) to the open field, indicating that $\mathrm{N}$ is more limiting than $\mathrm{P}$ for open field wheat.

In A. tortilis-maize systems, under canopy treatments showed consistently lower NUE values compared with open field conditions (Fig. 6a). NUE was $35 \%$ higher for

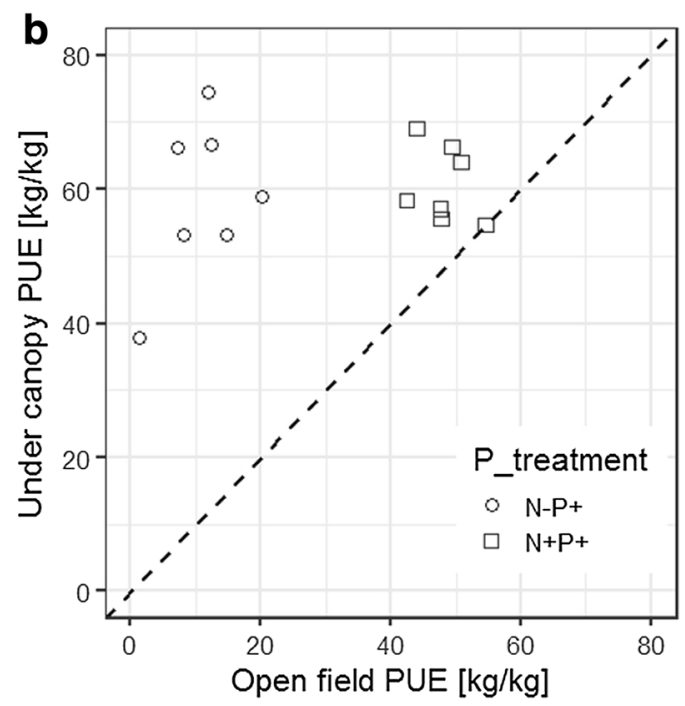

$N^{+} P^{-}, N P^{+}$and $N^{+} P^{+}$indicate nitrogen only, phosphorus only and combined nitrogen and phosphorus fertilizers, respectively. Broken lines represent 1:1 lines. 

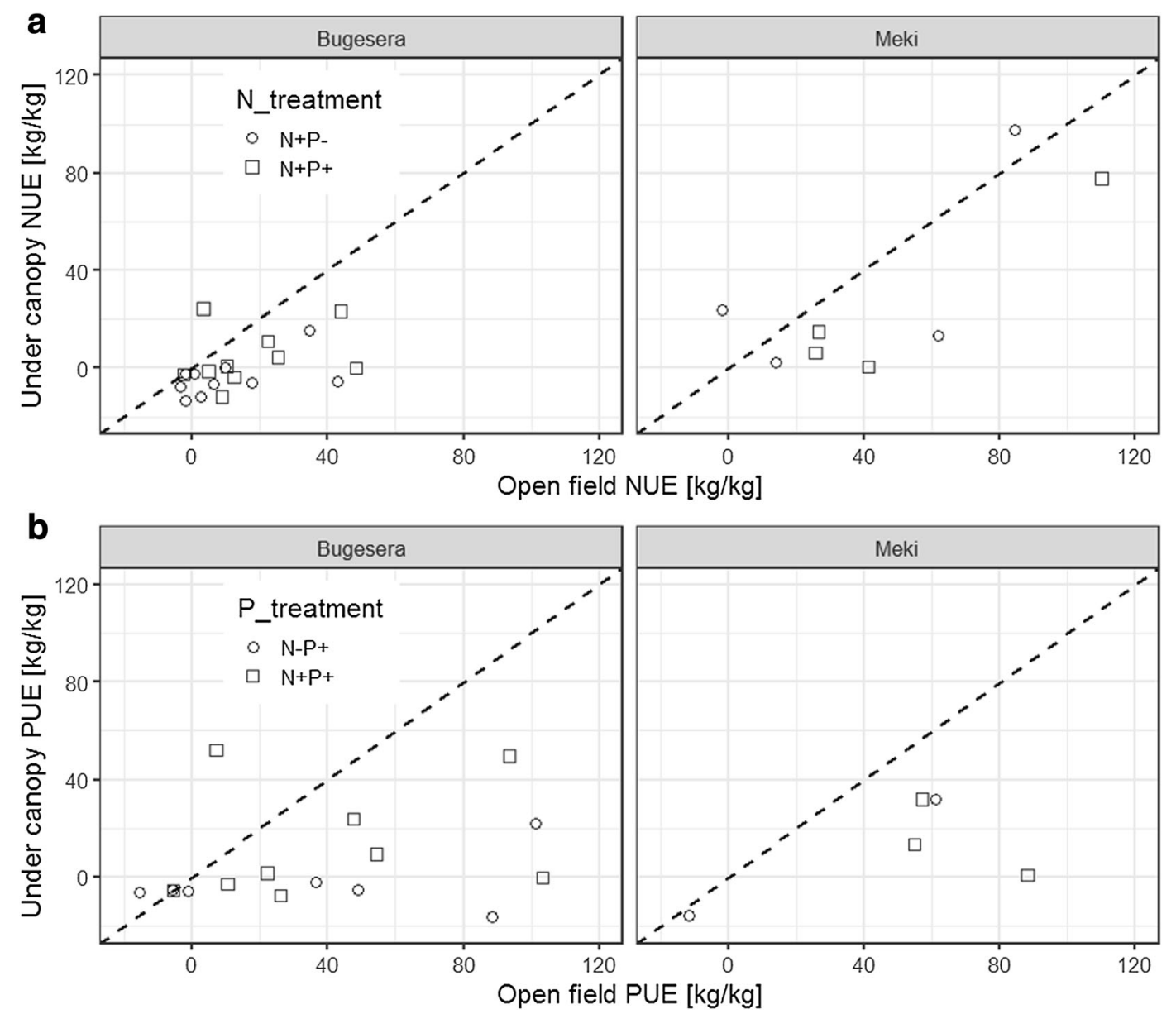

Fig. 6 Comparison of nitrogen use efficiencies (NUE) (a) and phosphorus use efficiencies (PUE) (b) of maize in open conditions and under the canopy of G. robusta (Bugeseara) and A. tortilis

open field maize (48.3 $\mathrm{kg}$ of grain for every $\mathrm{kg}$ of $\mathrm{N}$ added) compared with under canopy maize $(31.4 \mathrm{~kg}$ of grain for every $\mathrm{kg}$ of $\mathrm{N}$ added). Similarly, PUE in maize was $9 \%$ higher for open field plots compared with under canopy plots (Fig. 6b). The inefficient nutrient use does not appear to be related to the sole availability of nutrients between under canopy and open-field soils (Table S1).

In $G$. robusta-maize systems, the majority of under canopy maize showed inefficient utilization of nitrogen and phosphorus, as evidenced by negative NUE (Fig. 6a) and PUE (Fig. 6b). NUE was $13.2 \mathrm{kgkg}^{-1}$ for open field conditions, while it was extremely low for under canopy treatments $(0.1 \mathrm{~kg}$ of grain for every $\mathrm{kg}$ of $\mathrm{N}$ added). Similarly, the PUE was significantly lower for under canopy maize $(0.5 \mathrm{~kg}$ of grain for every $\mathrm{kg}$ of $\mathrm{P}$ added) compared with open field maize in Bugesera (29 $\mathrm{kg}$ of grain for every $\mathrm{kg}$ of $\mathrm{P}$ added). Under the
(Meki). $N^{+} P^{-}, N^{-} P^{+}$and $N^{+} P^{+}$indicate nitrogen fertilizer only, phosphorus fertilizer only and combined nitrogen and phosphorus fertilizers, respectively. Broken lines represent 1:1 lines.

current study, the type of mineral fertilizer applied to under canopy maize did not cause significant variation in the nutrient use efficiencies of maize associated to G. robusta. This may imply the existence of factors in addition to nutrient affecting nutrient utilization by under canopy maize.

\section{Discussion}

The outcome of fertilizer-tree-crop interactions depends on tree species and crop type

Our results clearly demonstrated that different on-farm tree species interact uniquely with crops, resulting in different responses to $\mathrm{N}$ and $\mathrm{P}$ fertilization. With the exception of $F$. albida, perhaps the most ideal 
agroforestry species, the other two tree species under the current study raised the old question of tree-crop compatibility for optimum productivity (German et al. 2006). While maintaining these trees in the system is beneficial for biodiversity and associated ecosystem services (Pattanayak and Mercer 1998; Bhagwat et al. 2008) and income generation (Steffan-Dewenter et al. 2007; Sida et al. 2018a), our results raise at least two main concerns. The first is whether fertilizer recommendations should consider tree-induced heterogeneity, which is common in many farming systems of SSA to address the negative effects of these trees on crops. The second is whether these systems require redesign such that trees are rearranged in ways that minimize their negative effects on crops.

On the other hand, tree-crop compatibility appears to be dictated by the type of associated crop. Wheat under the canopies of $F$. albida responded positively to tree presence. This contrasts with maize, which usually underperforms in the presence of trees (Ndoli et al. 2018). Similarly, Noumi et al. (2011) reported from the Mediterranean ecosystem that $A$. tortilis shades suppressed yields more in wheat than barley.

In A. tortilis-maize system, low yields and crop failures were more probable under tree canopy compared with open field conditions. This could be due to the fact that tree-crop competition is particularly high for this tree species and will intensify under moisture stress condition (Noumi et al. 2011). In support of this, Rao et al. (1997) argued that the positive influence of scattered trees on crops may be offset by large competition of trees with crops for water, especially during dry seasons. Low yields and complete crop failures observed in our study could also be attributed to such competitions. Because tree shades can cause significant delay in the vegetative development of understorey crops (Page et al. 2011), crops may fail due to shortage of moisture at the grain filling stage.

Similarly, the probability of low yield and crop failure were higher under tree canopy than under open field condition for $G$. robusta-maize systems. This agrees with the findings of Ong et al. (2000), which showed crop failures to be more prevalent under the canopy of G. robusta. Other studies have suggested that presence of trees poses consistently negative effects on grain formation in $G$. robusta-maize systems, affirming that the increased probability of crop failure could be due to competition (Muthuri et al. 2005).
Interestingly, the probability of low yield and crop failure varied with the NP fertilization in tree-crop systems (Fig. 2). In both A. tortilis-maize and $G$. robusta-maize systems, treatments that involved $\mathrm{N}$ fertilizer (i.e., $\mathrm{N}$ only and combined $\mathrm{NP}$ ) reduced the probability of low yield and crop failure. Moser et al. (2006) demonstrated that grain yield increased with an increasing $\mathrm{N}$ rate for maize exposed to pre-anthesis resource limitation (moisture and nutrient stresses). $\mathrm{N}$ fertilizer improved yields under the canopy indicating that competition for $\mathrm{N}$ was part of the reason for yield suppression under the canopy. This seems, at least partly to explain, why application of $\mathrm{N}$-containing fertilizers (N only and NP) reduced the probability of low yield and crop failure. In addition, the significant positive response to fertilizer under trees may reveal that nutrients were more limiting than other resources, especially under tree-crop environments.

Crop response to $\mathrm{N}$ and $\mathrm{P}$ fertilization varies with the tree-crop system

Results from our omission trials in $F$. albida-wheat systems revealed that $\mathrm{N}$ was strongly limiting in the open field soils of the study area (Fig. 2), contrasting with under canopy soils. For example, under canopy treatments that received no fertilizer and open field plots that received $\mathrm{N}$ only resulted in comparable wheat yields. This suggests that this tree contributes, directly or indirectly, mineral $\mathrm{N}$ about $64 \mathrm{~kg} \mathrm{~N} \mathrm{ha}^{-1} \mathrm{yr}^{-1}$, which conforms to recent findings by Yengwe et al. (2017), who reported $F$. albida to fix about $96 \mathrm{~kg} \mathrm{~N} \mathrm{ha}^{-1} \mathrm{yr}^{-1}$ (i.e., $18 \mathrm{~kg} \mathrm{~N} \mathrm{ha}^{-1} \mathrm{yr}^{-1}$ from litter decomposition in addition to about $78 \mathrm{~kg} \mathrm{~N} \mathrm{ha}^{-1}$ year $^{-1}$ from native soil organic matter).

Application of $\mathrm{P}$ only caused a contrasting response in wheat yield for under canopy and open field conditions. Open field plots that received P only fertilization did not respond compared with the open field control, while addition of $\mathrm{P}$ only to under canopy plots resulted in large gains in wheat yield. This could refute the suggestion that $F$. albida trees might selectively establish on initially fertile spots (Nair 1993). Although, Dangasuk et al. (2011) reported that $F$. albida improved available $\mathrm{P}$ underneath its canopy, our results suggest that phosphorus limited wheat yields under canopy. However, $\mathrm{N}$ may become limiting once $\mathrm{P}$ and other nutrients are no longer limiting. 
Our results imply that wheat yields may be improved under F. albida with minimum $\mathrm{N}$ fertilization. However, further research is needed to assess the optimum crop stage to apply this small amount of N: e.g., at planting, booting or first node stage, the three stages when N uptake by wheat is high (Justes et al. 1994). Our results also suggested that farmers practicing agroforestry with $F$. albida might invest their limited resources on localized $\mathrm{P}$ application instead of $\mathrm{N}$ fertilization.

In A. tortilis-maize systems, under canopy grain yield was not statistically different between all fertilizer treatments, suggesting that $\mathrm{N}$ and $\mathrm{P}$ may not be limiting in these systems. Although A. tortilis is known to fix nitrogen (Schulze et al. 1991), we did not observe any positive nutrient impact of the tree on the crop growing under its canopies. The presence of trees had a clear negative effect on maize yield. This could be explained by the dense root system of $A$. tortilis in the top soil (unlike roots of $F$. albida that penetrate deep) overlapping with maize roots, intensifying competition for nutrients and soil water (Belsky 1994). Stressing the importance of competition for soil moisture under A. tortilis, Noumi et al. (2011) demonstrated that crop yields under the canopy of this species were significantly higher during relatively wet years compared with relatively dry years. Our findings also agree with Larcher (2000) who showed soil moisture stress, not nutrients, to be the most important factor determining crop yield under the canopies of this tree. In addition, under canopy maize could not respond to nutrients as a result of heavy shade known to reduce photosynthesis in graminacea (Belsky 1994).

While fertilization rates under the current study were those recommended for conventional conditions, our results suggest that the application of fertilizer in combination with $A$. tortilis did not influence maize yield. In addition to tree canopy and root management to reduce tree-crop competition (Lehmann et al. 1998; Jackson et al. 2000), further study to disentangle alternative fertilization practices that may reduce tree-crop competition in A. tortilis-maize systems is required.

In Rwanda, the presence of $G$. robusta resulted in an average yield decline of $75 \%, 61 \%, 59 \%$ and $38 \%$ for control, N only, P only, and combined NP fertilizers, respectively, compared with maize outside the canopy with similar fertilization. While maize yields for $\mathrm{N}$ alone and $\mathrm{P}$ alone treatments were generally comparable, the highest yields were always recorded in the treatments that received combined NP for both under the canopy and the open field. The lowest yield decline (38\%) under the canopy of G. robusta as compared with the corresponding open field treatment was observed for combined NP fertilizer application, suggesting that higher $\mathrm{N}$ and $\mathrm{P}$ rates compensate for tree-crop competition. This result corroborates earlier findings of maize grain yield being affected by shade at kernel setting stage when faced with nutrient limitation (Andrade et al. 2002), resulting from competition between trees and crops. A recent study also reported that the shade from trees may affect grain formation negatively by decreasing kernel rows per head and kernels per row (Cui et al. 2015), although additional negative effects from root competition is expected in agroforestry systems (Callaway and Walker 1997). An interesting trend in G. robusta-maize system was the significant increase in yield with additional fertilizer, suggesting that fertilizer rates other than currently recommended for open field systems might optimize under canopy maize yield. As G. robusta is known for its timber (Bertomeu 2006) and phosphorus mobilization (Lambers and Shane 2007), higher rates of mineral fertilizer could improve its contribution to the overall productivity of the system.

The contrasting outcomes (i.e., yield declines in $G$. robusta and A. tortilis and yield improvement in F. albida) in fertilizer-tree-crop combinations could be related to the differences in tree root plasticity, which is a process that affects the root's foraging capacity depending on the nutrient availability surrounding the root (Leitner et al. 2010; Chen et al. 2013; Henke et al. 2014). From root excavation studies on $G$. robusta in Rwanda (Ndoli et al. 2016), F. albida and A. tortilis in Ethiopia (Sida et al. 2016), only F. albida showed a deep tap root with few laterals. G. robusta and A. tortilis had dense lateral roots mostly concentrated in the top soil. According to Chen et al. (2013) roots can adjust the direction of growth following resource gradient. In this case, the laterally branching roots of G. robusta and A. tortilis could behave in such a way, which could be the reason why we did not observe much improvement from nutrients added under their canopies. By contrast, the deep penetrating roots of $F$. albida may not respond in a similar manor, because the chance of these roots becoming in contact with the soil $\mathrm{P}$ patches (created by treatments applied under a single tree) is lower.

\section{Tree presence modifies crop NUE and PUE}

It has been established that combinations of organic materials and mineral fertilizer can improve nutrient 
use efficiencies in crops (Goyal et al. 1999; Han et al. 2004). As trees add organic matter to the soil through litter fall, dead roots and $\mathrm{N}_{2}$ fixation for some species, nutrient use efficiencies could be higher for crops growing under their canopies. Addition of $\mathrm{N}$ to the soil in the form of $\mathrm{N}_{2}$ fixation may increase NUE in two ways. It improves the total amount of available $\mathrm{N}$ under nitrogen-deficient conditions (Hirel et al. 2011), while it improves nitrogen availability under nitrogen-rich conditions (Xu et al. 2012). Our results confirmed this assertion for F. albida-wheat system, where NUE was larger for under canopy wheat. Similarly, PUE was doubled for wheat under the canopy of $F$. albida. This F. albida effect is interesting, as inefficient $\mathrm{P}$ use has been a major constraint in agricultural systems across the tropics (Simpson et al. 2011). In SSA, where limited availability of $\mathrm{P}$ is a critical limitation in cereal production, F. albida-based agroforestry systems could improve food security in the regions where this tree dominates.

However, the presence of G. robusta and A. tortilis resulted in inferior nutrient use efficiencies in maize. $\mathrm{N}$ and $\mathrm{P}$ deficiencies, which are likely to happen because of competition from tree roots, could be one of the causes for low nutrient use efficiencies (Simpson et al. 2011). The other explanation for the inefficiencies could be low radiation penetration resulting in low rates of photosynthesis in maize (Setter et al. 2001). Although nutrient use efficiencies by maize are low and often negative in tree-crop systems, van Noordwijk and Brussaard (2014) argued that system level nutrient use efficiency analysis (for example, if the yield of G. robusta were included in the analysis) may give a different perspective. According to Sida et al. (2018a), a farm-scale comparative analysis of ecosystem services, which included A. tortilis from the same region, indicated that farmers' rationale to maintain scattered trees within crop fields were not for yield purposes alone. The trade-offs that arose from the presence of these trees were off-set by the fuel wood, conservation, construction and social values obtained from these trees.

Limitations and recommendations for future studies

While this study has highlighted the need for adapting fertilizer application in heterogeneous tree-crop systems, stronger conclusions have been constrained by an unbalanced experimental design, the lack of soil fertility data and possible effects of root plasticity in response to resource patches created from our treatments. In future studies that aim to explore optimum fertilization in tree-crop systems, a balanced design combining more crops with single tree species and a single crop with more tree species would lead to a better understanding of mineral fertilizer-tree-crop interactions, particularly in highly heterogeneous farming systems as the ones considered in this study. Inclusion of soil fertility parameters and a larger number of replicates would also enhance our understanding of the mechanistic processes involved in these interactions.

\section{Conclusions}

The current study demonstrated that tree-crop interactions are mediated by the application of $\mathrm{N}$ and $\mathrm{P}$ fertilizers in tree-crop systems. In F. albida-wheat agroforestry systems, $\mathrm{N}$ fertilizers could be saved, with localized application of $\mathrm{P}$ fertilizers close to tree crowns. In G. robusta-maize and A. tortilis-maize agroforestry systems, maize did not respond to $\mathrm{N}$ and $\mathrm{P}$ fertilizers applied at recommended rates, although the application of these nutrients compensated for competition. This implies that mineral fertilizers can offset the effect of competition, while they fail to provide the yield advantages similar to mono-cropping situations. Thus, the current study highlighted the fact that fertilizer recommendations need to be adapted to agroforestry systems. However, in order to quantify the exact magnitude and nature of fertilizer-tree interaction in agroforestry systems accurately, factorial application of higher and lower rates of mineral fertilizer is needed. In addition, further research is needed to identify fertilization rates that minimize tree-crop competition for G. robustamaize and $A$. tortilis-maize systems, while additional studies are needed to identify the rates and timing of application that optimize F. albida-wheat facilitation.

Acknowledgements This work was implemented by CIMMYT and Wageningen University as part of the project 'Trees for Food Security' (FSC/2012/014), made possible by the generous support of the Australian Centre for International Agricultural Research (ACIAR), CRP MAIZE (www.maize.org) and CRP WHEAT (www.wheat.org). We also acknowledge three anonymous reviewers whose comments have immensely improved the quality of this manuscript. Any opinions, findings, conclusion, or recommendations expressed in this publication are those of the authors and do not necessarily reflect the view of ACIAR, CRP MAIZE and CRP WHEAT. 
Open Access This article is distributed under the terms of the Creative Commons Attribution 4.0 International License (http:// creativecommons.org/licenses/by/4.0/), which permits unrestricted use, distribution, and reproduction in any medium, provided you give appropriate credit to the original author(s) and the source, provide a link to the Creative Commons license, and indicate if changes were made.

\section{References}

Akinnifesi FK, Makumba W, Sileshi G, Ajayi OC, Mweta D (2007) Synergistic effect of inorganic $\mathrm{N}$ and $\mathrm{P}$ fertilizers and organic inputs from Gliricidia sepium on productivity of intercropped maize in southern Malawi. Plant Soil 294:203-217

Andrade FH, Calvino P, Cirilo A, Barbieri P (2002) Yield responses to narrow rows depend on increased radiation interception. Agron J 94:975-980

Bargués Tobella A, Reese H, Almaw A, Bayala J, Malmer A, Laudon H, Ilstedt U (2014) The effect of trees on preferential flow and soil infiltrability in an agroforestry parkland in semiarid Burkina Faso. Water Resour Res 50:3342-3354

Barrett CB, Bevis LE (2015) The self-reinforcing feedback between low soil fertility and chronic poverty. Nat Geosci 8:907

Bayala J, Balesdent J, Marol C, Zapata F, Teklehaimanot Z, Ouedraogo S (2007) Relative contribution of trees and crops to soil carbon content in a parkland system in Burkina Faso using variations in natural $13 \mathrm{C}$ abundance. Advances in integrated soil fertility management in sub-Saharan Africa: challenges and opportunities. Springer, pp. 161-169

Bayala J, Van Noordwijk M, Lusiana B, Ni'matul K, Teklehaimanot Z, Ouedraogo S (2008) Separating the treesoil-crop interactions in agroforestry parkland systems in Saponé (Burkina Faso) using WaNuLCAS. Toward agroforestry design. Springer, pp. 285-297

Bayala J, Sanou J, Teklehaimanot Z, Ouedraogo S, Kalinganire A, Coe R, Van Noordwijk M (2015) Advances in knowledge of processes in soil-tree-crop interactions in parkland systems in the west African Sahel: a review. Agric Ecosyst Environ 205:25-35

Belsky AJ (1994) Influences of trees on savanna productivity: tests of shade, nutrients, and tree-grass competition. Ecology 75: 922-932

Bertomeu M (2006) Financial evaluation of smallholder timberbased agroforestry systems in Claveria, northern Mindanao, the Philippines. Smal Scal Fors 5:57-81

Bertomeu M, Roshetko JM, Rahayu S (2011) Optimum pruning intensity for reducing crop suppression in a Gmelina-maize smallholder agroforestry system in Claveria, Philippines. Agrofor Syst 83:167-180

Bhagwat SA, Willis KJ, Birks HJB, Whittaker RJ (2008) Agroforestry: a refuge for tropical biodiversity? Trends Ecol Evol 23:261-267

Callaway RM, Walker LR (1997) Competition and facilitation: a synthetic approach to interactions in plant communities. Ecology 78:1958-1965
Chen YL, Dunbabin VM, Postma JA, Diggle AJ, Siddique KH, Rengel Z (2013) Modelling root plasticity and response of narrow-leafed lupin to heterogeneous phosphorus supply. Plant Soil 372:319-337

Cui D, Wu D, Liu J, Li D, Xu C, Li S, Li P, Zhang H, Liu X, Jiang C (2015) Proteomic analysis of seedling roots of two maize inbred lines that differ significantly in the salt stress response. PLoS One 10:e116697

Dangasuk OG, Gudu SO, Okalebo JR (2011) Survival and soil nutrient changes during 5 years of growth of 16 Faidherbia albida provenances in semi-arid Baringo District, Kenya. In: Bationo A, Waswa B, Okeyo JM, Maina F, Kihara JM (eds) Innovations as key to the green revolution in Africa: exploring the scientific facts. Springer Netherlands, Dordrecht, pp 227-234

German LA, Kidane B, Shemdoe R (2006) Social and environmental trade-offs in tree species selection: a methodology for identifying niche incompatibilities in agroforestry. Springer

Giller KE (2001) Nitrogen fixation in tropical cropping systems. $\mathrm{CAB}$ International, Wallingford

Gnankambary Z, Bayala J, Malmer A, Nyberg G, Hien V (2008) Decomposition and nutrient release from mixed plant litters of contrasting quality in an agroforestry parkland in the south-Sudanese zone of West Africa. Nutr Cycl Agroecosyst 82:1-13

Goyal S, Chander K, Mundra M, Kapoor K (1999) Influence of inorganic fertilizers and organic amendments on soil organic matter and soil microbial properties under tropical conditions. Biol Fertil Soils 29:196-200

Han K-H, Choi W-J, Han G-H, Yun S-I, Yoo S-H, Ro H-M (2004) Urea-nitrogen transformation and compost-nitrogen mineralization in three different soils as affected by the interaction between both nitrogen inputs. Biol Fertil Soils 39:193-199

Henke M, Sarlikioti V, Kurth W, Buck-Sorlin GH, Pagès L (2014) Exploring root developmental plasticity to nitrogen with a three-dimensional architectural model. Plant Soil 385:49-62

Hirel B, Tétu T, Lea PJ, Dubois F (2011) Improving nitrogen use efficiency in crops for sustainable agriculture. Sustainability 3:1452-1485

Jackson N, Wallace J, Ong C (2000) Tree pruning as a means of controlling water use in an agroforestry system in Kenya. For Ecol Manag 126:133-148

Justes E, Mary B, Meynard J-M, Machet J-M, Thelier-Huché L (1994) Determination of a critical nitrogen dilution curve for winter wheat crops. Ann Bot 74:397-407

Kuyah S, Dietz J, Muthuri C, Jamnadass R, Mwangi P, Coe R, Neufeldt H (2012) Allometric equations for estimating biomass in agricultural landscapes: II. Belowground biomass. Agric Ecosyst Environ 158:225-234

Lahmar R, Bationo BA, Dan Lamso N, Guéro Y, Tittonell P (2012) Tailoring conservation agriculture technologies to West Africa semi-arid zones: building on traditional local practices for soil restoration. Field Crop Res 132:158-167

Lambers H, Shane M (2007) Role of root clusters in phosphorus acquisition and increasing biological diversity in agriculture. Frontis 21:235-248 
Larcher W (2000) Temperature stress and survival ability of Mediterranean sclerophyllous plants. Plant Biosystems 134: 279-295

Lehmann J, Peter I, Steglich C, Gebauer G, Huwe B, Zech W (1998) Below-ground interactions in dryland agroforestry. For Ecol Manag 111:157-169

Leitner D, Klepsch S, Bodner G, Schnepf A (2010) A dynamic root system growth model based on L-systems. Plant Soil 332:177-192

Martin D, Moss J (1997) Age determination of Acacia tortilis (Forsk.) Hayne from northern Kenya. Afr J Ecol 35:266-277

Moser SB, Feil B, Jampatong S, Stamp P (2006) Effects of preanthesis drought, nitrogen fertilizer rate, and variety on grain yield, yield components, and harvest index of tropical maize. Agric Water Manag 81:41-58

Muthuri CW, Ong CK, Black CR, Ngumi VW, Mati BM (2005) Tree and crop productivity in Grevillea, Alnus and paulownia-based agroforestry systems in semi-arid Kenya. For Ecol Manag 212:23-39

Nair PR (1993) An introduction to agroforestry. Springer Science \& Business Media, Dordrecht, Netherlands

Ndoli A, Sida TS, Baudron F (2016) Tillage options and maize varieties that minimize tree-crop competition in Eastern African semi-arid agroforestry systems. In: Baudron, F. (Ed.), improving sustainable productivity in farming systems and enhanced livelihoods through adoption of evergreen agriculture in eastern Africa ('trees for food security project'). ACIAR (Australian Center for International Agricultural Research), Canberra, Australia

Ndoli A, Baudron F, Schut AGT, Mukuralinda A, Giller KE (2017) Disentangling the positive and negative effects of trees on maize performance in smallholdings of northern Rwanda. Field Crop Res 213:1-11

Ndoli A, Baudron F, Sida TS, Schut AG, van Heerwaarden J, Giller KE (2018) Do open-pollinated maize varieties perform better than hybrids in agroforestry systems? Exp Agric:1-13

Noumi Z, Abdallah F, Torre F, Michalet R, Touzard B, Chaieb M (2011) Impact of Acacia tortilis ssp. raddiana tree on wheat and barley yield in the south of Tunisia. Acta Oecol 37:117-123

Ong CK, Black CR, Wallace JS, Khan AAH, Lott JE, Jackson NA, Howard SB, Smith DM (2000) Productivity, microclimate and water use in Grevillea robusta-based agroforestry systems on hillslopes in semi-arid Kenya. Agric Ecosyst Environ 80:121-141

Page ER, Liu W, Cerrudo D, Lee EA, Swanton CJ (2011) Shade avoidance influences stress tolerance in maize. Weed Sci 59: 326-334

Palm CA, Gachengo CN, Delve RJ, Cadisch G, Giller KE (2001) Organic inputs for soil fertility management in tropical agroecosystems: application of an organic resource database. Agric Ecosyst Environ 83:27-42

Pattanayak S, Mercer DE (1998) Valuing soil conservation benefits of agroforestry: contour hedgerows in the eastern Visayas, Philippines. Agric Econ 18:31-46

R Core Team (2017) R: a language and environment for statistical computing. R Foundation for statistical computing, Vienna URL http:/www.R-project.org/
Rao M, Nair P, Ong C (1997) Biophysical interactions in tropical agroforestry systems. Agrofor Syst 38:3-50

RSO (2003) Regional Government of Oromia. Lume Woreda Based Development Programme. Oromia Economic Study Project Office, Mojo

Sanchez PA, Shepherd KD, Soule MJ, Place FM, Buresh RJ, Izac A-MN, Mokwunye AU, Kwesiga FR, Ndiritu CG, Woomer PL (1997) Soil fertility replenishment in Africa: an investment in natural resource capital. Replenishing Soil Fertility in Africa $1-46$

Sanou J, Zougmoré R, Bayala J, Teklehaimanot Z (2010) Soil infiltrability and water content as affected by baobab (Adansonia digitata L.) and Néré (Parkia biglobosa (Jacq.) Benth.) trees in farmed parklands of West Africa. Soil Use Manag 26:75-81

Schulze E-D, Gebauer G, Ziegler H, Lange O (1991) Estimates of nitrogen fixation by trees on an aridity gradient in Namibia. Oecologia 88:451-455

Setter TL, Flannigan BA, Melkonian J (2001) Loss of kernel set due to water deficit and shade in maize. Crop Sci 41: $1530-1540$

Sida TS, Ndoli A, Baudron F (2016) Adapting fertilization to minimize tree-crop competition in eastern African agroforestry systems. In: Baudron, F. (Ed.), improving sustainable productivity in farming systems and enhanced livelihoods through adoption of evergreen agriculture in eastern Africa ('trees for food security project'). ACIAR (Australian Center for International Agricultural Research), Canberra, Australia

Sida TS, Baudron F, Deme DA, Tolera M, Giller KE (2018) Excessive pruning and limited regeneration: are Faidherbia albida parklands heading for extinction in the central Rift Valley of Ethiopia? Land Degrad Dev 29:1623-1633

Sida TS, Baudron F, Hadgu K, Derero A, Giller KE (2018a) Crop vs. tree: can agronomic management reduce trade-offs in tree-crop interactions? Agric Ecosyst Environ 260:36-46

Sida TS, Baudron F, Kim HK, Giller KE (2018b) Climate-smart agroforestry: Faidherbia albida trees buffer wheat against climatic extremes in the central Rift Valley of Ethiopia. Agric For Meteorol 2018:339-347

Sileshi G, Akinnifesi FK, Ajayi OC, Place F (2009) Evidence for impact of green fertilizers on maize production in subSaharan Africa: a meta-analysis. World Agroforestry Centre, Nairobi

Sileshi GW, Nyoka BI, Beedy TL, Chanyenga T (2014) Modelling the scaling of stem growth with crown size and optimum stocking densities for systematic grid plantation of Faidherbia albida. New For 45:699-714

Simpson RJ, Oberson A, Culvenor RA, Ryan MH, Veneklaas EJ, Lambers H, Lynch JP, Ryan PR, Delhaize E, Smith FA (2011) Strategies and agronomic interventions to improve the phosphorus-use efficiency of farming systems. Plant Soil 349:89-120

Steffan-Dewenter I, Kessler M, Barkmann J, Bos MM, Buchori D, Erasmi S, Faust H, Gerold G, Glenk K, Gradstein SR (2007) Tradeoffs between income, biodiversity, and ecosystem functioning during tropical rainforest conversion and agroforestry intensification. Proc Natl Acad Sci 104:4973-4978 
Teklay T, Nordgren A, Malmer A (2006) Soil respiration characteristics of tropical soils from agricultural and forestry landuses at Wondo genet (Ethiopia) in response to $\mathrm{C}, \mathrm{N}$ and $\mathrm{P}$ amendments. Soil Biol Biochem 38:125-133

Tittonell P, Giller KE (2013) When yield gaps are poverty traps: the paradigm of ecological intensification in African smallholder agriculture. Field Crop Res 143:76-90

van Noordwijk M, Brussaard L (2014) Minimizing the ecological footprint of food: closing yield and efficiency gaps simultaneously? Curr Opin Environ Sustain 8:62-70

Vanlauwe B, Kihara J, Chivenge P, Pypers P, Coe R, Six J (2011) Agronomic use efficiency of $\mathrm{N}$ fertilizer in maize-based systems in sub-Saharan Africa within the context of integrated soil fertility management. Plant Soil 339:35-50

Verdoodt A, Van Ranst E (2003) Land evaluation for agricultural production in the tropics. A large-scale land suitability classification for Rwanda. Ghent University. Laboratory of Soil Science

Xu G, Fan X, Miller AJ (2012) Plant nitrogen assimilation and use efficiency. Annu Rev Plant Biol 63:153-182

Yengwe J, Gebremikael MT, Buchan D, Lungu O, De Neve S (2017) Effects of Faidherbia albida canopy and leaf litter on soil microbial communities and nitrogen mineralization in selected Zambian soils. Agrofor Syst

Yirga C, Hassan RM (2010) Social costs and incentives for optimal control of soil nutrient depletion in the central highlands of Ethiopia. Agric Syst 103:153-160

Publisher's note Springer Nature remains neutral with regard to jurisdictional claims in published maps and institutional affiliations. 